\title{
METABOLIC PROFILING, IN SILICO DOCKING AND ANTIBACTERIAL POTENTIAL OF PHYTOCONSTITUENTS FROM Phyllanthus muellerianus LEAVES
}

\author{
Tolulope Obuotor \\ Federal University of Agriculture Abeokuta \\ KOLAWOLE AMOS \\ Federal University of Agriculture Abeokuta \\ oladayo apalowo ( $\square$ apalowooladayo@gmail.com ) \\ Obafemi Awolowo University https://orcid.org/0000-0002-2495-3944 \\ Adio AKANMO \\ Federal University of Agriculture Abeokuta
}

\section{Research Article}

Keywords: in silico docking, quindoline, ciprofloxacin, hydrogen bond, HMG-CoA

Posted Date: May 26th, 2021

DOl: https://doi.org/10.21203/rs.3.rs-552990/v1

License: () (i) This work is licensed under a Creative Commons Attribution 4.0 International License.

Read Full License 


\section{Abstract}

Global increase in the level of antimicrobial resistance among bacterial pathogens has prompted the search for alternative treatment from medicinal plants. Phyllanthus muellerianus (PM) leaves has been used traditionally against microorganisms of medical importance, hence the need to evaluate the pharmacological pathways and mode of actions using in vitro and in silico approaches. Clinical isolates of eight (8) microorganisms associated with urinary tract infections (UTIS) were obtained and identified using morphological and biochemical methods. Phyllanthus muellerianus (PM) leaves were extracted and purified by solvent partitioning. Ethyl acetate fraction of PM had the highest yield and zone diameter range from $13.5 \pm 1.00 \mathrm{~mm}$ to $28 \pm 1.53 \mathrm{~mm}$. The rate of protein leakage per time interval of Staphylococcus aureus increased from $9.29 \mu \mathrm{g} / \mathrm{ml}$ at 0 minute to $17.43 \mu \mathrm{g} / \mathrm{ml}$ at 120 minutes while leakage in Candida albicans also increased from $8.57 \mu \mathrm{g} / \mathrm{ml}$ at 0 minute to $70.43 \mu \mathrm{g} / \mathrm{ml}$ at 120 minutes. GCMS fingerprints, pharmacodynamics and pharmacokinetic studies revealed the active agent as quindoline, an azaindoles and isoteres of indoles having a binding energy of $-9.1 \mathrm{kcal} / \mathrm{mol}$. Analyses of the structural and atomic orientations of quindoline, and superimposition on ciprofloxacin, a common antibiotic revealed an interesting comparison, effecting a stronger binding affınity of Quindoline-HMG-CoA complex.

\section{Full Text}

This preprint is available for download as a PDF. 